\title{
Morphological response of a sandy barrier island with a buried seawall during Hurricane Sandy
}

\author{
Stephanie M. Smallegan ${ }^{1 *}$, Jennifer L. Irish ${ }^{1}$, Ap R. Van Dongeren ${ }^{2}$, Joost \\ P. Den Bieman ${ }^{2}$ \\ ${ }^{1}$ Department of Civil and Environmental Engineering, Virginia Tech, Blacksburg, \\ Virginia 24061, USA \\ ${ }^{2}$ Deltares, Delft, Netherlands \\ *Corresponding author: ssmalls@vt.edu
}

\begin{abstract}
Coastal populations continue to increase globally, causing potential damage costs of coastal hazards to rise and community resiliency to become a worldwide priority. Recently, Hurricane Sandy (2012) devastated areas of New York and New Jersey and caused overwash and breaching of several urbanized barrier islands along the U.S. eastern seaboard. This study focuses on the morphological response of Bay Head, NJ, a township on a barrier island fronted with a buried seawall. The hydrodynamics and morphology of Bay Head during Hurricane Sandy are simulated with XBeach, a numerical model designed to study these processes during storm events. From the simulations, the seawall protected Bay Head by effectively dissipating wave energy during the peak of the storm and from rapidly increasing bay water levels that flood the backbarrier region of the island. When the seawall is removed from the simulation, dune heights are lowered, allowing bay side flooding to cause a devastating erosive event that completely destroys the remaining dune system. XBeach indicates severe erosion seaward of ocean-
\end{abstract}


front buildings in the absence of a seawall (vertical erosion under the dune peak about $15 \mathrm{~m}$ more than in the presence of the seawall), and wave energy propagates further inland even after the storm has passed. However, with the seawall present, wave attack is reduced on the island by a factor of 1.7 and prevents bay side flooding from causing significant morphological change on the island. Therefore, the seawall increased resiliency of the Bay Head community during and after peak Hurricane Sandy forcing by preserving the dune system.

Keywords: XBeach, Hurricane Sandy, armored dune, barrier island

\section{Introduction}

Globally, coastal populations continue to grow, further increasing the need to develop sustainable communities resilient to coastal hazards (Hinrichsen, 1999; Neumann et al., 2015; Small and Nicholls, 2003). In 2000, an estimated $10 \%$ of the world's population lived in coastal zones with elevations of less than $10 \mathrm{~m}$ above sea level, which are highly vulnerable to damage from waves and flooding (McGranahan et al., 2007). Because of the concentration of urban development in these areas, coastal populations are expected to continue to increase, leading to new infrastructure and higher potential costs due to coastal storm events. These costs include tangible and intangible losses, such as physical damage to infrastructure, ecosystem loss and degradation, business and social disruptions and loss of life (Donnelly et al., 2006; Escudero et al., 2014; Kraus and Wamsley, 2003). Smith et al. (2015) have shown that, in the U.S. from 1980 to 2014, 50\% of the direct economic damage caused by natural disasters were due to tropical cyclones. 
In other words, costs of coastal hazards are nearly equal to the combined costs of all other major natural disasters, placing a significant burden on the U.S. economy.

By accurately predicting the behavior of developed coastal areas during storm conditions and coupling the results with appropriate risk analyses (Escudero Castillo et al., 2012), city planners can make better-informed decisions on sustainable infrastructure development and protection measures. However, the precise extent of storm-induced beach erosion, especially along barrier islands, is currently difficult to predict. Barrier islands, which make up $6.5 \%$ of the world's open ocean coastlines (Stutz and Pilkey, 2001), are the mainland coasts' first line of defense against storms, but they are susceptible to severe damage by overwash and breaching.

Overwash deposits are the landward transport of sediment from its originating dune, which lowers dune heights and increases vulnerability to damage from subsequent storms. However, overwash fans can also create new habitat, including those for endangered or threatened species (Dennison et al., 2012). In extreme cases, breaching can occur, which is the formation of a channel across a barrier island. Breaching occurs most commonly on narrow islands with low frontal dune heights. It can destroy infrastructure as the channel is formed (Donnelly et al., 2006; Sallenger, 2000), but it can also reduce flooding from storm surge by equilibrating water levels on the ocean and bay sides (Kraus and Wamsley, 2003). Although both processes can have positive environmental and ecological impacts, they are often detrimental to urbanized coasts.

To reduce storm damage along sandy beaches, combinations of nature- 
based and hard structures, such as armored dunes, have been implemented in several locations globally because they are more cost-effective and environmentally sustainable with respect to the use of hard structures alone (Basco, 1998). Examples in the U.S. include Virginia Beach, VA (Basco, 1998, 2000; U.S. Army Corps of Engineers [USACE], 2008), Galveston, TX (Gibeaut et al., 2003), and Jekyll Island, GA (Yang et al., 2010, 2012). However, the force-reducing effects of these combination of nature-based and hard protection designs have not been quantitatively assessed in the field, since it is not possible to remove the structure, recreate the same storm conditions at that location, and compare island responses with and without a structure present. Some laboratory studies, as summarized by Kraus and McDougal (1996), indicated seawalls, which were exposed in most of the experiments, can cause localized increases in erosion, but the net volume of sediment transported was generally less or about the same for cases with a hard structure compared to cases without a hard structure. Morton (1976) qualitatively described erosion around a seawall near Panama City Beach, FL during Hurricane Eloise (1975), but the seawall's effectiveness as a protective structure was not assessed. Irish et al. (2013) described a buried seawall in Bay Head, NJ, which was exposed during the peak of Hurricane Sandy (2012). In their study, the seawall's effectiveness at reducing wave forces was assessed during the peak of the storm using a Boussinesq-type wave model, where the dune shape was static and the seawall was presumed to be exposed throughout the numerical simulations. This approach yielded a factor of two wave force reduction with respect to a "no seawall" case.

In this study, we aim to evaluate the storm force-reducing effects of a 
dynamic sandy dune with a buried seawall when subject to storm conditions. Specifically, we use the numerical model, XBeach, to simulate hydrodynamics and morphology of Bay Head, NJ under Hurricane Sandy forcing. We then analyze the morphological response of the barrier island and the wave force reducing capabilities of the sandy dune and buried seawall as it becomes exposed during the storm. Expanding the work by Irish et al. (2013), the full duration of Hurricane Sandy and the resulting sediment transport are simulated here.

\section{Methods}

\subsection{XBeach Model Description}

To simulate hydrodynamics and morphology during Hurricane Sandy, we use the numerical model XBeach, version 4613 (Roelvink et al., 2009). The two-dimensional (2D) depth-averaged model resolves infragravity waves, which have been shown to be of importance in the dune erosion process (Roelvink et al., 2009; Van Thiel de Vries, 2009). XBeach is capable of seamlessly modeling all four dune impact regimes as defined by (Sallenger, 2000), and model skill has been demonstrated on barrier islands (Lindemer et al., 2010; McCall et al., 2010) and urbanized coasts (Nederhoff, 2014; van Verseveld et al., 2015) among others. XBeach is chosen as the most appropriate numerical model to use, because it has been extensively validated for simulating morphological change over complex 2D bathymetry, and coastal structures can be represented as hard, non-erodable layers.

To calculate low frequency and mean flows, the nonlinear shallow-water wave equations are used. The radiation stress gradients, $F$, are determined 
by solving a wave action balance equation, which is coupled with a roller energy balance equation. Sediment transport is modeled using a depthaveraged advection diffusion Van Rijn - Van Thiel de Vries equation where sediment entrainment and deposition is determined by the difference between the depth-averaged and equilibrium sediment concentrations (Van Thiel de Vries, 2009).

Because XBeach does not resolve individual waves or full three-dimensional processes, some processes are parameterized using specifiable parameter values. In this study, most of these parameters are set to published default values; therefore, only parameters that were changed are discussed here. Since short wave runup can have a significant effect on morphology at the beach face (Van Thiel de Vries, 2012), this physical process is activated in all simulations, and the wave runup calibration coefficient, facrun, is specified to be 0.8 (default is 1.0, range is 0 to 2.0). Also, jetfac, an option used to mimic turbulence production near hard structures, is specified as 0.1 (default is 0, range is 0 to 1.0). Lastly, parameter facua, which governs onshore transport, is set to 0.25 (default is 0.1 , range is 0 to 1.0 ) to account for wave skewness in the model. The reader is referred to Roelvink et al. (2009) for full details of the XBeach model.

\subsection{Hurricane Sandy}

On 29 October 2012, Hurricane Sandy made landfall near Atlantic City, NJ (Figure 1) and devastated communities along the northeastern U.S. coastline. Hurricane Sandy originated from a tropical wave that entered the Caribbean Sea and intensified to a hurricane on 24 October. Prior to entering the Atlantic Ocean, the storm made direct landfall in Jamaica and Cuba. 
Then, on 29 October, the hurricane collided with a non-tropical weather system, locally known as a Nor'easter, which prevented Hurricane Sandy from moving offshore. Instead, the hybrid storm, often referred to as Superstorm Sandy, veered west making landfall in the U.S near Atlantic City, NJ at 23:30 GMT on 29 October (Blake et al., 2013).

The unusually large post-tropical storm had a radius of about $280 \mathrm{~km}$, maximum sustained winds of $130 \mathrm{~km} / \mathrm{h}$, and a minimum pressure of $945 \mathrm{mb}$ at landfall. Hurricane Sandy was also characterized by record storm surges and large waves lasting over several high tides (Blake et al., 2013; Irish et al., 2013). In total for the U.S., Hurricane Sandy caused 159 fatalities and damages are estimated as $\$ 67$ billion (USD) (Smith et al., 2015), making it the second-costliest hurricane since 1900 (Blake et al., 2013). Other physical damages were severe dune erosion, overwash and breaching of several barrier islands, including Fire Island, NY, Assateague Island, VA and along New Jersey. Hurricane Sandy left over 8.5 million customers without electricity on the order of weeks to months after landfall, caused health concerns, such as upper respiratory symptoms and worsened chronic conditions, and psychological impacts, including anxiety, sleep disturbances and posttraumatic stress (Blake et al., 2013; Lowe et al., 2015; Subaiya et al., 2014). A total of 24 states were impacted by Hurricane Sandy, ranging from gusting winds over the eastern seaboard and the Great Lakes to heavy snowfall in West Virginia and North Carolina, causing severe disturbances to businesses, land and air transportation, and social aspects (Blake et al., 2013; Halverson and Rabenhorst, 2013). 


\subsection{Study Area}

This study focuses on Bay Head, a township located along a barrier island in New Jersey (Figure 1). This island is a product of rapid post-glacial sea level rise and consists of Holocene beach and estuarine deposits, which are easily mobilized by waves and currents (Department of Environmental Protection, 1999; The Richard Stockton Coastal Research Center [RSCRC], 2015). Because the island is narrow, low-lying and mildly sloping, it is particularly vulnerable to storm surges (RSCRC, 2012; Williams, 2013). Although small patches of vegetation exist on the island, they are unable to protect Bay Head from large scale overwash during storm events, as has been observed in other locations (Feagin et al., 2015; RSCRC, 2012).

To help protect the island, over half of the shoreline is fronted with a rock seawall buried beneath a sand dune. The 1260-m long structure was originally built in 1882 and was extended in 1962 (Irish et al., 2013; Remington \& Boyd Engineers, 1962). In 1992, the seawall became exposed during a major Nor'easter, but was restored to its buried state, where it remained until Hurricane Sandy's impact (RSCRC, 2012). It has been noted that structural damage from Hurricane Sandy was substantially worse in areas not fronted with the seawall (Irish et al., 2013; RSCRC, 2012). This study aims to use a dynamic model to quantify the wave reducing effects of and protection afforded the buildings by the sandy dune that covers the seawall and the seawall as it became exposed during Hurricane Sandy. 


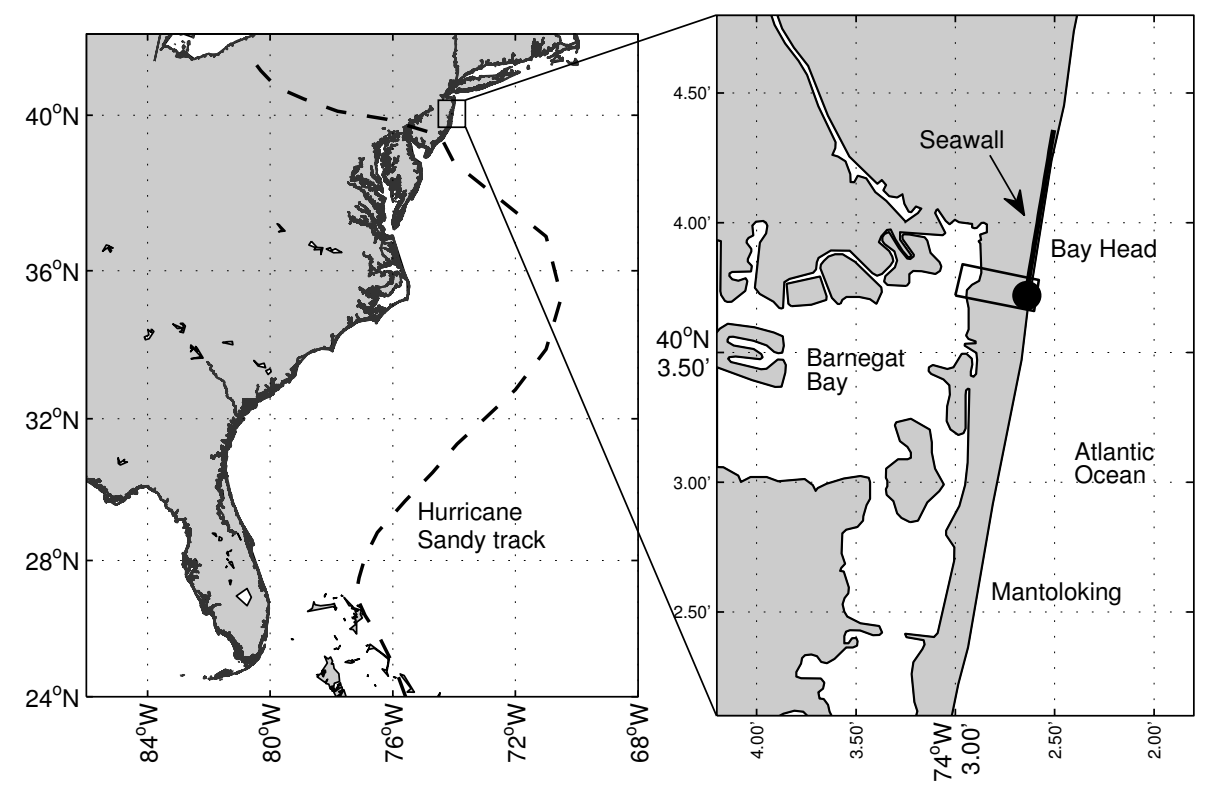

Figure 1: The study area is Bay Head, NJ (boxed, left panel) located north of Hurricane Sandy's landfall. Over half of Bay Head's shoreline is fronted with a buried seawall (solid black, right panel), and the area of interest modeled with XBeach extends northward 190 $\mathrm{m}$ from the south end of the seawall (boxed, right panel). An interior high water mark was measured as $4.6 \mathrm{~m}$ (black dot) within the area of interest (Irish et al., 2013).

\subsection{XBeach Model Setup}

\subsubsection{Model Grid}

The 2D bathymetric grid used in all simulations (Figure $2(\mathrm{a})$ ) is developed using pre-storm surveys of Bay Head near the southern end of the seawall. The domain origin is $40.06^{\circ} \mathrm{N}, 74.05^{\circ} \mathrm{W}$. Topography data are obtained from a U.S. Geological Survey (USGS) pre-storm first-return lidar survey, or "non-bare earth", collected in 2012 (USGS, 2012b) and a USACE pre-storm last-return lidar survey, representing the "bare earth", collected in 2010 (USACE, 2010). Since the 2012 bare earth data were not available at the time of 
this publication, the 2012 and 2010 data sets are combined such that the 2012 dune and shoreface are maintained, and 2010 bare earth data are used for all other island topography. This significantly reduces the noise caused by vegetation on the island, providing a more accurate representation of pre-storm conditions in Bay Head. In the nearshore region, one-dimensional (1D) crossshore profiles surveyed by RSCRC (2012) are interpolated and merged with the 2D topographic grid. Barnegat Bay bathymetry is obtained from lidar data collected by USGS in October 2012 prior to Hurricane Sandy's landfall (Wright et al., 2014). All remaining bathymetry data, including offshore depths, are extracted from the National Oceanic and Atmospheric Administration (NOAA) Coastal Relief Model (National Geophysical Data Center, 2013). A representative cross-shore profile of the topographic and bathymetric relief is given in Figure 2(b), with the seawall location and shape shown in the inset. 

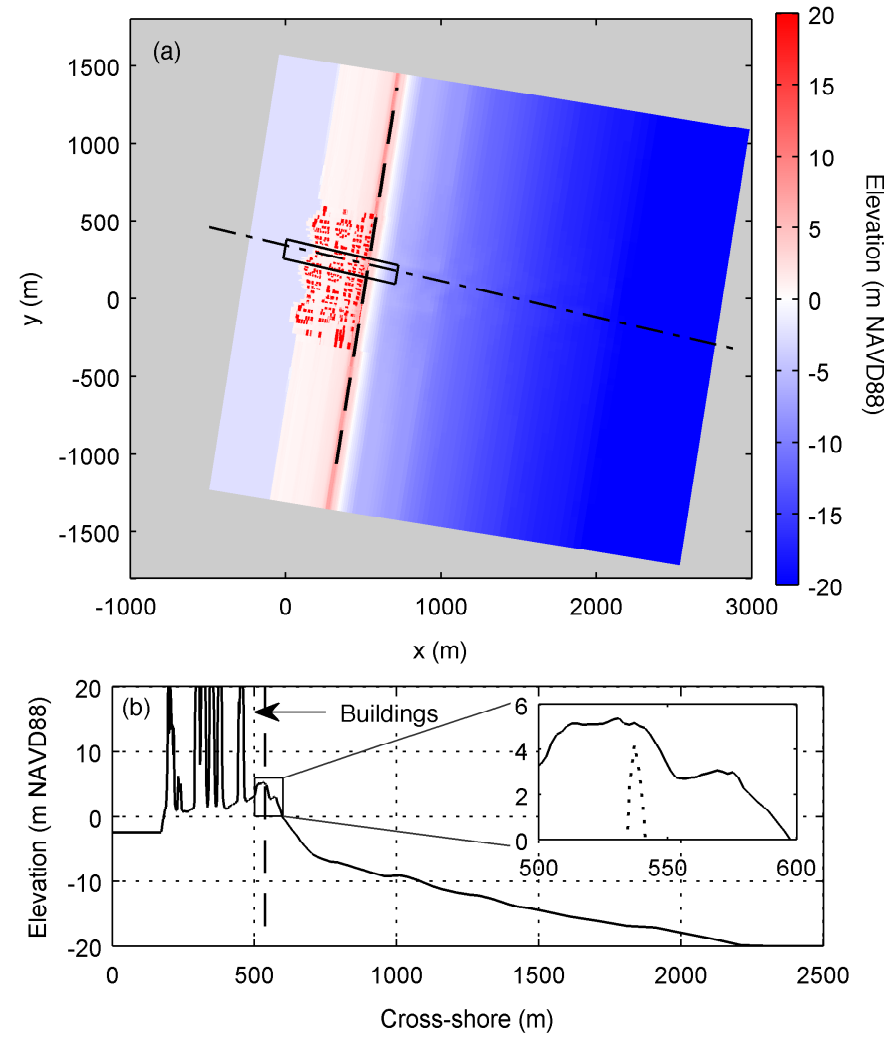

Figure 2: Data used for (a) the full model grid with cross-shore and longshore resolution ranging from $2 \mathrm{~m}$ to $50 \mathrm{~m}$, (b) a representative cross-shore profile (dash-dot line in (a)) and the buried seawall in the inset. Buildings (red polygons) and the seawall (black dash line) are input as hard structures. The boxed region in (a) is the area of interest with origin coordinates of $40.06^{\circ} \mathrm{N}, 74.05^{\circ} \mathrm{W}$.

Using satellite imagery available via Google Earth (Google, Inc., 2014), building locations and shapes are determined and superimposed onto island topography. At the building locations, grid cells are set as 'non-erodable', or as hard structures that do not erode. If the hard structure grid cells become "wet", sediment transport over and sediment deposition on the structures are 
possible. It should be noted that hard structures are indestructible in the model, i.e., buildings are not damaged or destroyed in the simulations. The seawall is also set as a hard structure located at $4.45 \mathrm{~m}$ NAVD88, or about 2 m beneath the dune crest, with 1:1 side slopes (Remington \& Boyd Engineers, 1962). Here, we have corrected the seawall elevation by accounting for sea level rise from 1962 to 2012 using the linear trend measured at a tide gauge in Atlantic City, NJ (4.08 mm/y) and converting from MSL to NAVD88 datum (NOAA Tides and Currents, 2012). The final grid resolution ranges from 2 $\mathrm{m}$ to $50 \mathrm{~m}$ in the cross-shore and longshore directions so that the seawall and buildings are sufficiently resolved.

\subsubsection{Wave and Surge Data}

In this study, Hurricane Sandy is modeled as a 74-hour storm beginning at 0030 GMT on 28 October 2012. Offshore spectral wave data are obtained from buoy 44025 (National Data Buoy Center, 2012). However, we observed energy in the low-frequency bands were truncated during the peak of the storm at some time steps. To account for this lost energy, the low-frequency data are fit with a linear trend extending from frequency bin $0.0425 \mathrm{~Hz}$, the lowest bin likely to contain energy, to the spectrum peak. Although the total energy increase for those time steps requiring adjustment is only $7.5 \%$ and there is a negligible change in model results, the adjusted energy spectra are consistent with measurements at other time steps and are more typical of hurricane wave conditions. The adjusted spectra are then used to drive SWAN, a third-generation wave model (Booij et al., 1999), which is used to transform waves from the $40 \mathrm{~m}$ buoy depth to the $20 \mathrm{~m}$ offshore boundary of the XBeach grid, beyond which depth one can expect significant 
morphological change. This step greatly reduces the required XBeach grid size, thereby reducing computational time by about $50 \%$.
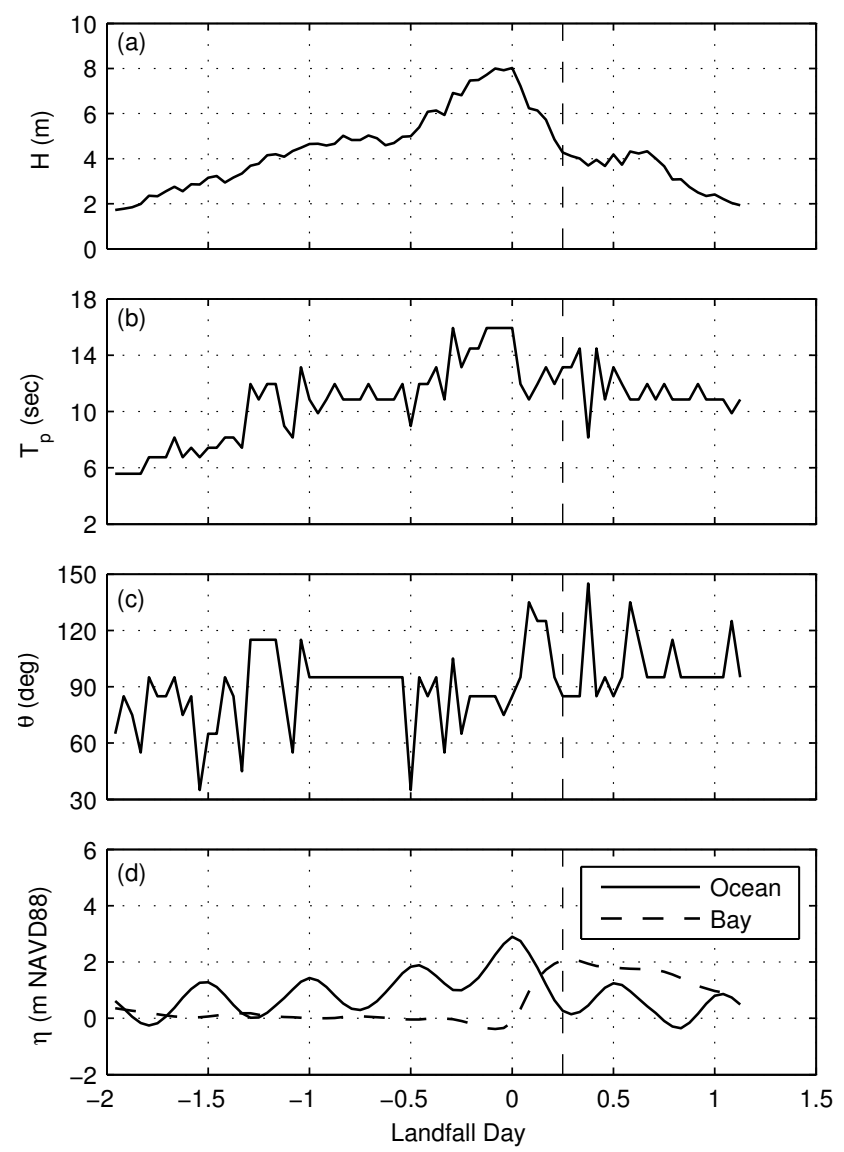

Figure 3: XBeach model inputs at 20-m depth for Hurricane Sandy: (a) wave height, $H$, (b) peak period, $T_{p}$, (c) wave direction, $\theta$, in nautical convention and (d) water level, $\eta$, of the ocean (solid) and bay (dash). The vertical dash line distinguishes Phase 1 (left) from Phase 2 (right), and 0 (zero) landfall day is specified at 2330 GMT on 29 October 2012.

Figure 3 gives wave conditions at the offshore boundary of the XBeach grid, and shows (a) $H$ reaches over $8 \mathrm{~m}$, (b) $T_{p}$ increases to $16 \mathrm{sec}$ during the peak of the storm corresponding to sea swell, and (c) waves are typically 
shore-normal $\left(100^{\circ}\right)$ with some waves approaching from the northeast at the beginning of the storm and from the southeast as the storm passes.

Due to record high storm surges experienced during Hurricane Sandy, the tide gauge nearest to Bay Head failed during the peak of the storm. However, the Stevens Estuarine and Coastal Ocean Model (sECOM) (Orton et al., 2012) has been shown to accurately simulate Hurricane Sandy surge levels at several other tide gauges, including gauges located to the north of Bay Head in Sandy Hook, NJ and the Battery, NY and to the south of Bay Head in Atlantic City, NJ (Nederhoff, 2014). Therefore, sECOM-simulated water levels at the XBeach offshore boundary are used for ocean surge input (Figure 3(d)). Barnegat Bay water levels near Bay Head are from the USGS National Water Information System (2012) gauge 01408168 (Figure 3(d)), which shows a $2 \mathrm{~m}$ increase within 8 hours after Hurricane Sandy's landfall.

Two phases of Hurricane Sandy impact are distinguished by the vertical dash line in Figure 3. Phase 1 occurs from the beginning of the simulation until 0.25 landfall day (6 hours after landfall) and is characterized by strong waves and ocean surge that exceed bay water levels. Phase 2 is characterized by weaker waves and bay water levels higher than ocean water levels. The impact of these phases on morphology are discussed in Section 3.2.

\section{Results and Discussion}

\subsection{XBeach Validation}

Using the previously described data as input in XBeach, the hydrodynamics, sediment transport and morphological change near the southern end of the seawall in Bay Head are modeled for Hurricane Sandy conditions. The 
south end of the seawall is chosen because the island width is relatively narrow and backed by Barnegat Bay at this location, allowing overwash and breaching to become possible and bay side hydrodynamics to affect island response. This area also provides robustness to the model validation. Several studies have validated XBeach on natural systems absent of infrastructure (e.g. McCall et al. (2010)), but our study area includes a buried seawall, around which XBeach must accurately simulate morphological change. The pre-storm model input is shown in Figure 4(a), and the grid has been rotated such that the seawall is located at $x=533 \mathrm{~m}$. To validate the model setup, the post-Sandy first return lidar survey (Figure 4(b)) completed by USGS on 05 November 2012 (USGS, 2012a) is compared to the final simulated island topography (Figure 4(c)). Although bare earth is not available, this data set is chosen for comparison because it was collected prior to the extensive human interaction immediately following the storm, namely re-burial of the seawall with sand. Thus, these data provide the most accurate post-storm survey, even though the data consist of significant noise caused by vegetation (Figure 4(b)).

In addition to comparing simulated to measured morphological change, the model setup is validated by comparing maximum simulated water levels to a high water mark collected during a post-storm field survey (Irish et al., 2013). XBeach simulates a maximum water level of $4.8 \mathrm{~m}$, which is comparable to the interior water mark elevation measured in Bay Head of 4.6 m. 

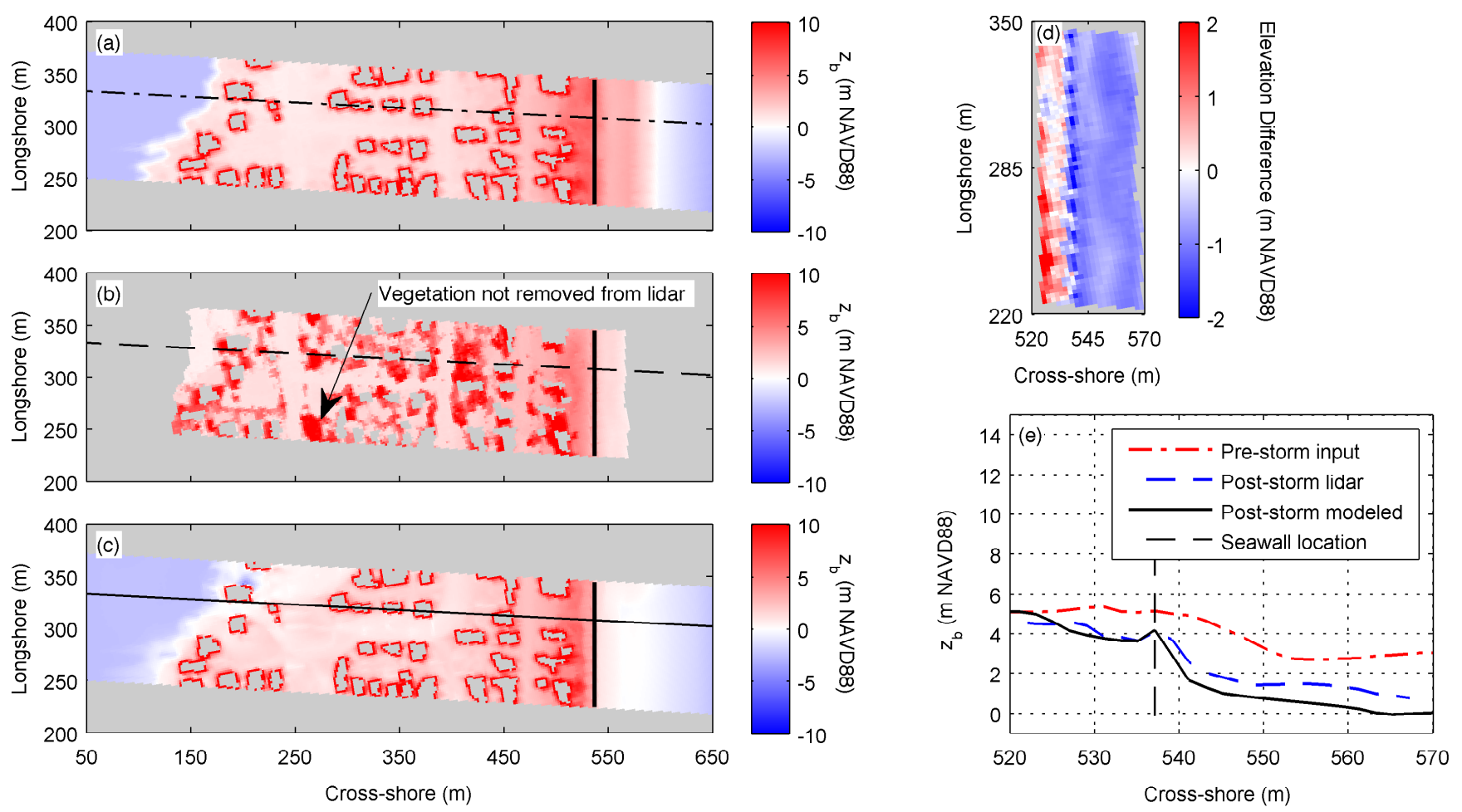

Figure 4: Data in the model domain: (a) elevation, $z_{b}$, of the pre-storm model input, (b) $z_{b}$ of the post-storm first return lidar survey where red patches are vegetation that were not removed in the data set, and (c) $z_{b}$ of the final XBeach result (seawall, black solid line); (d) elevation difference, $\Delta z_{b}$, between the final XBeach result and measured data (XBeach - lidar) for the dune and beach face region; (e) cross-shore profile (dash-dot line in (a), dash line in (b) and solid line in (c)) of pre-storm measurements (dash-dot), post-storm measurements (dash) and final XBeach result (solid). Building locations are shown in gray and domain origin is $40.06^{\circ} \mathrm{N}, 74.05^{\circ} \mathrm{W}$.

Due to noise in the lidar data, only the area around the seawall is considered for quantitative analysis to validate the model setup. For this area, the difference between the XBeach result and lidar data is shown in Figure 4 (d), such that cooler colors indicate areas of lower simulated elevations by 
XBeach. Overall, the measured and modeled data appear to be in good agreement, except for the seaward side of the seawall, where XBeach simulates more erosion than observed in lidar data. The model performance is evaluated using the Brier Skill Score (BSS) method described by Van Rijn et al. (2003):

$$
B S S=1-\frac{\left\langle\left(\left|z_{b, c}-z_{b, m}\right|-\Delta z_{b, m}\right)^{2}\right\rangle}{\left\langle\left(z_{b, 0}-z_{b, m}\right)^{2}\right\rangle}
$$

where $z_{b, c}$ is computed bed level, $z_{b, m}$ is measured bed level, $z_{b, 0}$ is initial bed level, $\Delta z_{b, m}$ is the error in measured data equal to $0.20 \mathrm{~m}$ (USGS, 2012a), and $\langle\ldots\rangle$ represents the average value. With this scale, a BSS equal to 1 indicates perfect model performance, a value of 0 means that the model performs as well as if no change were predicted, and a negative value means the model performs worse than predicting no change.

For areas around the dune and beach face, the BSS is 0.86, corresponding to "excellent" model performance as defined by Van Rijn et al. (2003). The bias is $-0.65 \mathrm{~m}$, which means XBeach overpredicts erosion, specifically on the seaward side and on top of the seawall. This bias has the same order of magnitude as prior work on a sandy barrier island (McCall et al., 2010) despite our study area being a built environment. There are several possible causes for this difference. Most notably, the seawall is assumed to have a uniform height in simulations, which may not be true of the rock structure in Bay Head. Also, the rock seawall allows some flow between its stones, but XBeach is currently unable to resolve this complex process. Instead, XBeach uses some of the incoming wave energy to simulate turbulence at the toe of the structure, which causes erosion on the seaward side of the seawall. Lastly, the beach face had been reworked by waves and several tidal cycles 
by the time the lidar survey was conducted, which may have caused sediment deposition in this area.

To provide a more detailed assessment of the results, data are extracted along the dash-dot, dash and solid lines in panels (a), (b) and (c) and plotted in Figure 4(e). The pre-storm dune height is significantly eroded during Hurricane Sandy, and the simulated result is in good agreement with measurements. For comparison purposes, this representative profile has a BSS of 0.89 and a bias of $-0.56 \mathrm{~m}$, which are similar to the BSS and bias of the region around the seawall.

\subsection{Morphological Response in the Presence and Absence of a Seawall}

To evaluate the morphological response of Bay Head in the presence and absence of a seawall, the seawall was removed from the previously described model setup and the storm re-simulated. From XBeach simulations, morphological change is substantially different in the two phases described in Section 2.4.2. By the end of Phase 1, wave attack and ocean surge cause erosion of the dune in the "seawall" case (Figure 5(a)) to the extent that the seawall becomes slightly exposed. A discussion on the temporal evolution of the dune profile is given below. In the "no seawall case", erosion is more severe due to island overwash, which causes the formation of channels through the dune and between buildings (Figure 5(b)). Figure 5(c) shows the elevation difference between the "seawall" and "no seawall" cases at the end of Phase 1 , which is relatively small $(+/-1 \mathrm{~m})$ except for the formation of these channels.

In Phase 2, a maximum of only $1 \mathrm{~m}$ of additional erosion occurs on the island in the presence of the seawall (Figure 5(d)). However, Figure 5(e) 
shows catastrophic island inundation, where erosion with a maximum of 6 $\mathrm{m}$ occurs at the dune peak and oceanfront buildings. Also, the channels formed during Phase 1 are deepened and widened during Phase 2, and the back barrier region is eroded to an average elevation of $-1.5 \mathrm{~m}$ NAVD88. Figure 5(f) shows elevation of the "no seawall" case is typically about $3 \mathrm{~m}$ less than the "seawall" case, with a maximum elevation difference of $15 \mathrm{~m}$. This large difference is due to erosion of the dune itself, which has an initial height of at least $6 \mathrm{~m}$ in the study area, and severe erosion in front of the first row of houses. 

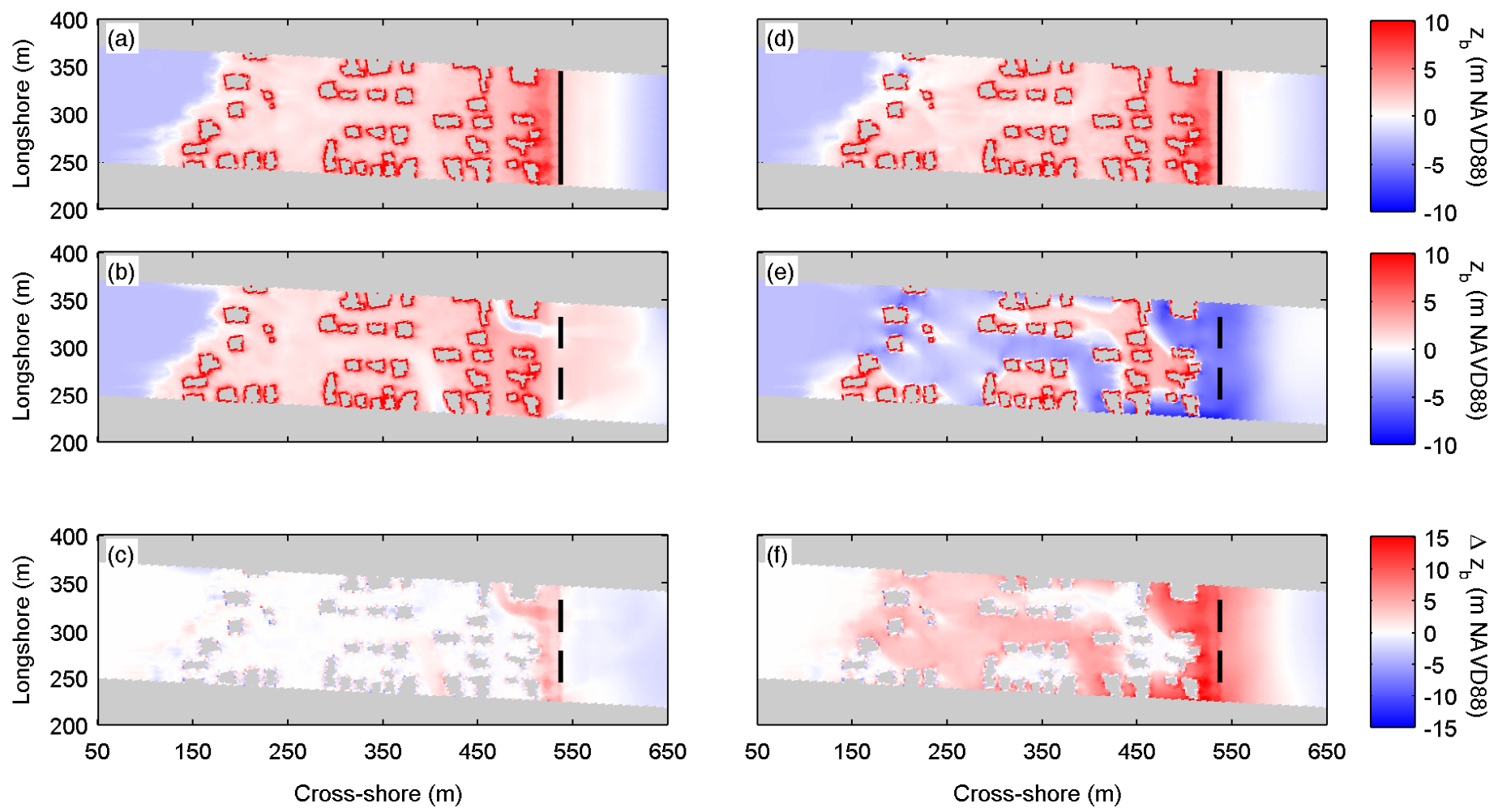

Figure 5: XBeach simulated bed levels: at the end of Phase 1 (a) "seawall" case, (b) "no seawall" case and (c) elevation difference, $\Delta z_{b}$, ("seawall" - "no seawall"); at the end of Phase 2 (d) "seawall" case, (e) "no seawall" case, and (f) $\Delta z_{b}$ ("seawall" - "no seawall"). The solid lines represent the seawall location and the dash lines show the location of the removed seawall. Building locations are shown in gray and domain origin is $40.06^{\circ} \mathrm{N}$, $74.05^{\circ} \mathrm{W}$.

The wave reducing effects of the dynamic sandy dune and buried seawall are quantified by analyzing the time evolution of wave force per area, $F_{x}$ (radiation stress gradient, $d S_{x x} / d x$, hereafter denoted as "force") along the representative profile in Figure 4 for the "seawall" and "no seawall" cases. This is shown in Figure 6(a) and (b). The storm impact regimes defined 
by Sallenger (2000) are used to evaluate Bay Head's morphological response to Hurricane Sandy and describe dune failure. These regimes are defined in terms of morphological change as follows:

- Swash $(\mathrm{S})$ - beach foreshore, or the region seaward of the dune and berm, erodes and sediment is deposited offshore,

- Collision (C) - toe of the dune erodes and sediment is deposited offshore,

- Overwash (O) - dune crest is overtopped and sediment is deposited landward,

- Inundation (I) - island is submerged and sediment is deposited further landward.

Initially, the island is in the swash regime since only the beach foreshore erodes. As waves become larger and ocean water levels increase, the dune begins to erode, which is characteristic of the collision regime. The sandy dune dissipates wave force until approximately 2.5 hours prior to Hurricane Sandy's landfall. At that time, the seawall becomes exposed, is slightly overtopped signifying the overwash regime, and is heavily impacted by maximum wave forces of nearly $2000 \mathrm{~N} / \mathrm{m}^{2}$. Because of the seawall, much of the dune system is preserved and wave force does not inundate the dune peak as the storm passes. However, in the absence of the seawall (Figure 6(b)), wave force propagates nearly $80 \mathrm{~m}$ further inland due to significant dune erosion during the peak of the storm, and the island enters the inundation regime. After the storm passes, wave force continues to propagate onto the island, since the dune is destroyed and no longer protects the island from wave action. 
In Figure 6(c) and (d), the time evolution of elevation change behind the seawall is shown for the representative cross-shore profile of the "seawall" and "no seawall" cases. In the presence of the seawall, no sediment is transported over the seawall prior to Hurricane Sandy's landfall. At the peak of the storm $(\mathrm{t}=0)$, about $1 \mathrm{~m}$ of sediment is eroded from behind the seawall, but no additional bed level change occurs for the remainder of the storm. However, in the absence of the seawall, over $3 \mathrm{~m}$ of erosion occurs at the dune peak when Hurricane Sandy makes landfall. Here, the distinction between Phases 1 and 2 can clearly be made at 0.25 landfall day due to the much larger erosive event (greater than $5 \mathrm{~m}$ dune erosion) caused by the sharp increase in bay water levels. 

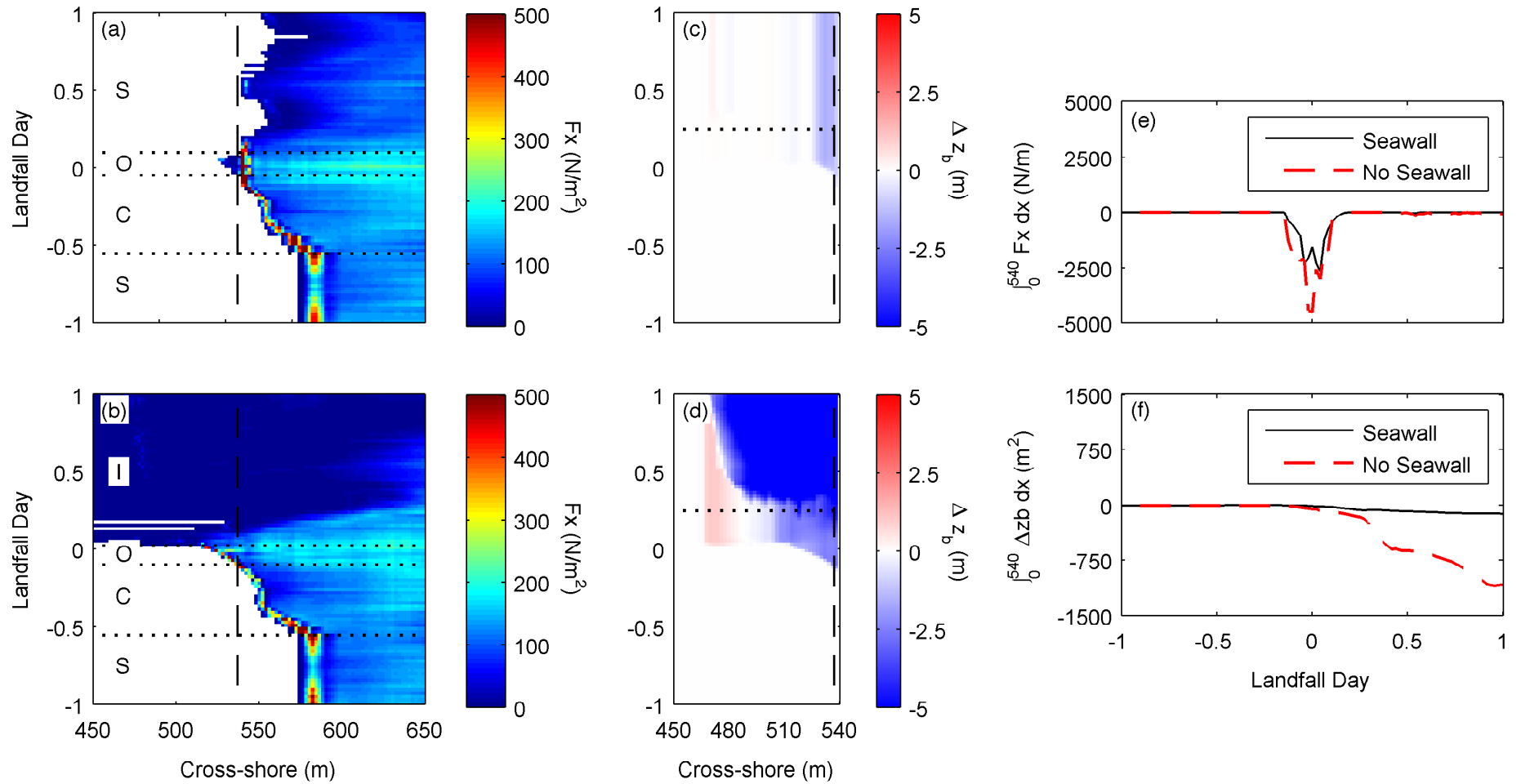

Figure 6: Time evolution with respect to landfall of Hurricane Sandy: (a) $F_{x}$ in the presence of the seawall, (b) $F_{x}$ in the absence of the seawall, (c) elevation change landward of the seawall location, $\Delta z_{b}$ (final - initial), of the "seawall" case, (d) $\Delta z_{b}$ of the "no seawall" case (cool colors indicate erosion), (e) integral of $F_{x}$ over cross-shore distance landward of the seawall and (f) integral of $\Delta z_{b}$ over cross-shore distance landward of the seawall (solid line is "seawall" case, dash line is "no seawall" case). $F_{x}$ is the wave force per unit area in the cross-shore direction extracted along the profile in Figure 4, and 0 (zero) landfall day is specified at 2330 GMT on 29 October 2012. Dashed lines in (a) - (d) show seawall location, dotted lines in (a) and (b) indicate storm impact regimes (Sallenger, 2000), and dotted lines in (c) and (d) distinguish Phase 1 (bottom) from Phase 2 (top).

By integrating force and elevation change behind the seawall with respect to cross-shore distance, the wave force reducing effects of the seawall are 
analyzed. Figure 6(e) shows a significant reduction in wave force during the peak of Hurricane Sandy in the "seawall" versus the "no seawall" case. The maximum wave force reduction factor is 1.7 , consistent with the findings of Irish et al. (2013) (maximum reduction factor of 2.0), even though XBeach and the Boussinesq model used in their study simulate physical processes differently. In Figure 6(f), the large erosive event in the "no seawall" case is clearly observed starting at about $t=0.25$ landfall day, but there is no morphological impact on the "seawall" case at that time.

\section{Conclusions}

To evaluate the morphological response of a developed barrier island fronted with a buried seawall, the numerical model XBeach is used to simulate hydrodynamics and morphological response of Bay Head, NJ during Hurricane Sandy (2012). From these results, the seawall in Bay Head clearly served to protect coastal infrastructure and preserve the dune system during and after the storm. XBeach simulations indicate morphological change during two phases. In Phase 1, wave attack and ocean surge reach maximum values, and the seawall reduces wave forces by a factor of 1.7. In the absence of the seawall, dune heights are lowered, making the island vulnerable to wave action and flooding. During Phase 2, wave attack is small, but bay water levels increase rapidly over $2 \mathrm{~m}$ within 6 hours after Hurricane Sandy's landfall, exceeding ocean water levels. Although this bay-side flooding caused catastrophic erosion in the absence of the seawall (an additional $5 \mathrm{~m}$ of sediment eroded), no significant additional erosion is observed in the "seawall" case since the dune system remained in tact. 
Although the results presented here are site and storm specific, the physical response of the sandy dune is realistic of other areas around the world with similar geology, i.e. narrow urbanized barrier island backed by a long narrow bay (Claudino-Sales et al., 2008; McCall et al., 2010; Sallenger, 2000; Silva et al., 2014). Therefore, we conclude the wave attenuation provided by the seawall is also physically realistic of performance of buried seawalls at other locations. Further investigations of armored dunes in other locations should be conducted under storm conditions to determine their possible benefit as protective structures. The feasibility of nature-based systems, such as additional beach nourishment or barrier island restoration, should also be evaluated since they can provide protection from flooding and breach formation without adding infrastructure to the beach (Cunniff and Schwartz, 2015; National Research Council, 2014). As identified by the present study, the effects of bayside hydrodynamics on morphological change of barrier islands are another topic of interest. Finally, some model limitations of this study include groundwater infiltration, rainwater runoff, and vegetation. These were not included in the simulations due to lack of available data or their relatively small effect on island morphology as observed from field data. Based on the reduction of across island erosion due to attenuation of wave forces by the sandy dune and seawall observed here, combination nature-based and hard structures may be a possible alternative for increasing coastal resiliency during storm events. 


\section{Acknowledgments}

The authors thank Dr. Philip Orton, Stevens Institute of Technology, for providing surge data from sECOM simulations. This research was supported by NOAA Virginia Sea Grant Graduate Research Fellowship Program, National Science Foundation Graduate Research Fellowship program via grant number DGE-1148903, and National Science Foundation via grant number EAR-1312813. A. van Dongeren and Joost P. den Bieman were supported through Deltares Research Program on "Hydro- and Morphodynamics during

Extreme Events". The authors acknowledge Advanced Research Computing at Virginia Tech for providing computational resources and technical support that have contributed to the results reported within this paper. URL: http://www.arc.vt.edu.

\section{References}

Basco, D.R., 1998. The economic analysis of "soft" versus "hard" solutions for shore protection: An example. Coastal Engineering Proceedings 1.

Basco, D.R., 2000. Beach monitoring results and management plan FCTCLANT, Dam Neck, Virginia Beach, VA. Technical Report. Beach Consultants, Inc.

Blake, E.S., Kimberlain, T.B., Berg, R.J., Cangialosi, J., Beven II, J.L., 2013. Tropical cyclone report: Hurricane Sandy. National Hurricane Center 12, $1-10$.

Booij, N., Ris, R., Holthuijsen, L.H., 1999. A third-generation wave model 
for coastal regions: 1. Model description and validation. Journal of Geophysical Research: Oceans (1978-2012) 104, 7649-7666.

Claudino-Sales, V., Wang, P., Horwitz, M.H., 2008. Factors controlling the survival of coastal dunes during multiple hurricane impacts in 2004 and 2005: Santa Rosa barrier island, Florida. Geomorphology 95, 295-315.

Cunniff, S., Schwartz, A., 2015. Performance of natural infrastructure and nature-based measures as coastal risk reduction features. Envionmental Defense Fund .

Dennison, W.C., Saxby, T., Walsh, B.M., 2012. Responding to major storm impacts: Chesapeake Bay and the Delmarva Coastal Bays.

Department of Environmental Protection, 1999. Geologic Map of New Jersey. Technical Report. Division of Science, Research and Technology Geological Survey.

Donnelly, C., Kraus, N., Larson, M., 2006. State of knowledge on measurement and modeling of coastal overwash. Journal of Coastal Research , 965-991.

Escudero, M., Mendoza, E., Silva-Casarín, R., Villatoro, M., 2014. Comparative risk assessment at Isla del Carmen and Cancun, Mexico. Coastal Engineering Proceedings 1, 10.

Escudero Castillo, M., Mendoza Baldwin, E., Silva Casarin, R., Posada Vanegas, G., Arganis Juaréz, M., 2012. Characterization of risks in coastal zones: A review. CLEAN-Soil, Air, Water 40, 894-905. 
Feagin, R.A., Figlus, J., Zinnert, J.C., Sigren, J., Martínez, M.L., Silva, R., Smith, W.K., Cox, D., Young, D.R., Carter, G., 2015. Going with the flow or against the grain? The promise of vegetation for protecting beaches, dunes, and barrier islands from erosion. Frontiers in Ecology and the Environment 13, 203-210.

Gibeaut, J.C., Hepner, T.L., Waldinger, R., Andrews, J.R., Smyth, R.C., Gutierrez, R., 2003. Geotubes for temporary erosion control and storm surge protection along the Gulf of Mexico shoreline of Texas. Proceedings of the 13th Biennial Coastal Zone Conference 13, 17.

Google, Inc., 2014. Google Earth version 7.1. http://www.google.com /earth/index.html, Accessed 12 April 2013.

Halverson, J.B., Rabenhorst, T., 2013. Hurricane Sandy: The science and impacts of a superstorm. Weatherwise 66, 14-23.

Hinrichsen, D., 1999. Coastal waters of the world: Trends, threats, and strategies. Island Press.

Irish, J.L., Lynett, P.J., Weiss, R., Smallegan, S.M., Cheng, W., 2013. Buried relic seawall mitigates Hurricane Sandy's impacts. Coastal Engineering 80, 79-82.

Kraus, N.C., McDougal, W.G., 1996. The effects of seawalls on the beach: Part I, an updated literature review. Journal of Coastal Research , 691701.

Kraus, N.C., Wamsley, T.V., 2003. Coastal Barrier Breaching. Part 1. Overview of Breaching Processes. Technical Report. DTIC Document. 
Lindemer, C., Plant, N., Puleo, J., Thompson, D., Wamsley, T., 2010. Numerical simulation of a low-lying barrier island's morphological response to Hurricane Katrina. Coastal Engineering 57, 985-995.

Lowe, S.R., Sampson, L., Gruebner, O., Galea, S., 2015. Psychological resilience after Hurricane Sandy: The influence of individual-and community-level factors on mental health after a large-scale natural disaster. PloS one, e0125761.

McCall, R., De Vries, J.V.T., Plant, N., Van Dongeren, A., Roelvink, J., Thompson, D., Reniers, A., 2010. Two-dimensional time dependent hurricane overwash and erosion modeling at Santa Rosa Island. Coastal Engineering 57, 668-683.

McGranahan, G., Balk, D., Anderson, B., 2007. The rising tide: Assessing the risks of climate change and human settlements in low elevation coastal zones. Environment and urbanization 19, 17-37.

Morton, R.A., 1976. Effects of Hurricane Eloise on beach and coastal structures, Florida Panhandle. Geology 4, 277-280.

National Data Buoy Center, 2012. Station 44025 (LLNR 830) - Long Island 30 NM South of Islip, NY. National Oceanic and Atmospheric Administration. http://www.ndbc .noaa.gov/station_page $\cdot$ php?station $=44025$, Accessed 26 September 2014.

National Geophysical Data Center, 2013. National Geophysical Data Center, U.S. Coastal Relief Model. National Oceanic and Atmospheric Adminis- 
tration. http://www.ngdc.noaa.gov/mgg/coastal/crm.html, Accessed 21 August 2013.

National Research Council, 2014. Reducing coastal risk on the East and Gulf Coasts. National Academies Press.

Nederhoff, C., 2014. Modeling the effects of hard structures on dune erosion and overwash: Hindcasting the impact of Hurricane Sandy on New Jersey with XBeach. Master's thesis. Delft University of Technology.

Neumann, B., Vafeidis, A.T., Zimmermann, J., Nicholls, R.J., 2015. Future coastal population growth and exposure to sea-level rise and coastal flooding-a global assessment. PloS one 10, e0118571.

NOAA Tides and Currents, 2012. NOAA Tides and Currents, Atlantic City, NJ Station ID: 8534720. National Oceanic and Atmospheric Administration. http://tidesandcurrents.noaa.gov/, Accessed 12 April 2013.

Orton, P., Georgas, N., Blumberg, A., Pullen, J., 2012. Detailed modeling of recent severe storm tides in estuaries of the New York City region. Journal of Geophysical Research: Oceans (1978-2012) 117.

Remington \& Boyd Engineers, 1962. Construction plans: Stone seawall and groins, Borough of Bay Head, Ocean County, New Jersey. Technical Report Project number 9:02-420-401-881. Department of Conservation and Economic Development.

Roelvink, D., Reniers, A., Van Dongeren, A., de Vries, J.V.T., McCall, R., Lescinski, J., 2009. Modelling storm impacts on beaches, dunes and barrier islands. Coastal Engineering 56, 1133-1152. 
Sallenger, A.H., 2000. Storm impact scale for barrier islands. Journal of Coastal Research , 890-895.

Silva, R., Martínez, M.L., Hesp, P.A., Catalan, P., Osorio, A.F., Martell, R., Fossati, M., Miot da Silva, G., Mariño-Tapia, I., Pereira, P., et al., 2014. Present and future challenges of coastal erosion in Latin America. Journal of Coastal Research 71, 1-16.

Small, C., Nicholls, R.J., 2003. A global analysis of human settlement in coastal zones. Journal of Coastal Research , 584-599.

Smith, A., Lott, N., Houston, T., Shein, K., Crouch, J., 2015. BillionDollar U.S. Weather and Climate Disasters 1980 - 2014. Technical Report. National Oceanic and Atmospheric Administration.

Stutz, M.L., Pilkey, O.H., 2001. A review of global barrier island distribution. Journal of Coastal Research , 15-22.

Subaiya, S., Moussavi, C., Velasquez, A., Stillman, J., 2014. A rapid needs assessment of the Rockaway Peninsula in New York City after Hurricane Sandy and the relationship of socioeconomic status to recovery. American Journal of Public Health 104, 632-638.

The Richard Stockton Coastal Research Center [RSCRC], 2012. Beach-dune Performance Assessment of New Jersey Beach Profile Network (NJBPN) Sites at Northern Ocean County, New Jersey After Hurricane Sandy Related to FEMA Disaster DR-NJ 4086. Technical Report. The Richard Stockton College of New Jersey. Pomona, NJ. 
The Richard Stockton Coastal Research Center [RSCRC], 2015. New Jersey Coastal Composition.

U.S. Army Corps of Engineers, 2010. 2010 USACE lidar: New Jersey. http://www.csc.noaa.gov/digitalcoast/data/coastallidar/download, Accessed 31 July 2013.

U.S. Army Corps of Engineers [USACE], 2008. Coastal Engineering Manual, Part. V., Chapter 3 Shore Protection Projects, EM 1110-2-110. Coastal and Hydraulics Lab., US Army Engineer Research and Development Center, Vicksburg, Mississippi, USA .

U.S. Geological Survey, 2012a. 2012 USGS EAARL-B Lidar: PostSandy (NJ). St. Petersburg Coastal and Marine Science Center. http://www.csc.noaa.gov/digitalcoast/data/coastallidar/download, Accessed 30 September 2014.

U.S. Geological Survey, 2012b. 2012 USGS EAARL-B Lidar: PreSandy (NJ). St. Petersburg Coastal and Marine Science Center. http://www.csc.noaa.gov/digitalcoast/data/coastallidar/download, Accessed 30 June 2014.

U.S. Geological Survey National Water Information System, 2012. USGS 01408168 Barnegat Bay at Mantoloking NJ. U.S. Geological Survey. http://waterdata.usgs.gov/usa/nwis/uv?01408168, Accessed 14 January 2014.

Van Rijn, L., Walstra, D., Grasmeijer, B., Sutherland, J., Pan, S., Sierra, J., 2003. The predictability of cross-shore bed evolution of sandy beaches at 
the time scale of storms and seasons using process-based profile models. Coastal Engineering 47, 295-327.

van Verseveld, H., van Dongeren, A., Plant, N., Jäger, W., den Heijer, C., 2015. Modelling multi-hazard hurricane damages on an urbanized coast with a bayesian network approach. Coastal Engineering 103, 1-14.

Van Thiel de Vries, J.S.M., 2009. Dune erosion during storm surges. Ph.D. thesis. TU Delft, Delft University of Technology.

Van Thiel de Vries, J.S.M., 2012. Dune erosion above revetments. ICCE 2012: Proceedings of the 33rd International Conference on Coastal Engineering, Santander, Spain, 1-6 July 2012 .

Williams, S.J., 2013. Sea-level rise implications for coastal regions. Journal of Coastal Research 63, 184-196.

Wright, C.W., Troche, R.J., Klipp, E.S., Kranenburg, C.J., Fredericks, A.M., Nagle, D.B., 2014. EAARL-B submerged topography: Barnegat Bay, New Jersey, pre-Hurricane Sandy, 2012. Technical Report Data Series 885. U.S. Geological Survey. http://pubs .er .usgs .gov/publication/ds885, Accessed 14 November 2014.

Yang, B., Hwang, C., Cordell, H.K., 2012. Use of lidar shoreline extraction for analyzing revetment rock beach protection: A case study of Jekyll Island State Park, USA. Ocean \& Coastal Management 69, 1-15.

Yang, R.Y., Wu, Y.C., Hwung, H.H., Liou, J.Y., Shugan, I.V., 2010. Current countermeasure of beach erosion control and its application in Taiwan. Ocean \& Coastal Management 53, 552-561. 